\title{
Aktivitas Penghambatan Olssidasi Asam Linoleat Ekstralk Metanol Daun Soyogik (Saurauia bracteosa DC) dengan Metode Ferric Thiocyanate
}

\author{
Marsella Rottya*, Max R. J. Runtuwenea, Vanda S. Kamua \\ Jurusan Kimia, FMIPA, Unsrat, Manado
}

KATA K UNCI

Saurauia bracteosa DC

Fenolik

Ferric Thiocyanate

\begin{abstract}
A B S T R A K
Telah dilakukan penelitian untuk menentukan kandungan total fenolik dan aktivitas antioksidan ekstrak metanol daun soyogik (Saurauia bracteosa DC) sebagai peredam radikal bebas asam linoleat. Kandungan total fenolik diukur dengan metode Folin-Ciocalteu sedangkan aktivitas antioksidan diukur dengan metode FTC (Ferric Thiocyanate) untuk mengetahui kemampuan penghambatan peroksida pada tahap pertama oksidasi lipid. Hasil penelitian menunjukkan bahwa ekstrak metanol memiliki kandungan total fenolik sebesar 99,67 mg/kg dan kemampuan dalam menghambat oksidasi asam linoleat sebesar 49,464\%.
\end{abstract}

K E Y W O R D S

Saurauia bracteosa DC

Phenolic

Ferric Thiocyanate

\section{A B S T R A C T}

This research has been conducted to measure the total phenolic compounds and the antioxidant activity of methanol extract of soyogik leaves (Saurauia bracteosa DC) as a reducer of free radicals linoleic acid. The total phenolic content was measured using folin-ciocalteu method, meanwhile the antioxidant activity was measured using FTC (Ferric Thiocyanate) method and to determine the peroxide inhibitory capability in the first stages of lipid peroxidation. The results showed that the methanol extract had a total phenolic content of $99,67 \mathrm{mg} / \mathrm{kg}$ and peroxide inhibition of $49,464 \%$
TERSEDIA ONLINE

01 Agustus 2017
1. Pendahuluan

Asam lemak adalah asam karboksilat yang bersama-sama dengan gliserol merupakan penyusun utama minyak atau lemak. Penambahan lemak pada proses pengolahan pangan berfungsi untuk menambah kalori serta memperbaiki tekstur dan cita rasa bahan pangan. Asam lemak dibedakan menjadi asam lemak jenuh dan tak jenuh (Sartika, 2008). Minyak yang mengandung asam lemak tak jenuh jamak (Polyunsaturated Fatty Acid/ PUFA) diakui dapat menurunkan kolesterol darah serta meningkatkan nilai kesehatan lainnya. Namun, jika digunakan untuk menggoreng secara berulang-ulang, maka asam lemak tak-jenuh (baik dari minyak penggoreng maupun dari makanan yang digoreng) akan berubah menjadi asam lemak 'Trans', gugus peroksida serta senyawa radikal bebas lainnya (Tuminah, 2009).
Oksidasi akan menghasilkan produk oksidasi primer berupa peroksida yang dapat mengalami degradasi menjadi produk oksidasi sekunder seperti aldehid, dan keton yang menyebabkan terjadinya ketengikan. Untuk mengetahui tingkat ketengikan dari lipid, dapat dilakukan dengan menentukan jumlah peroksida yang telah terbentuk pada lipid tersebut yang diukur menggunakan metode Ferric Thiocyanate (FTC) (Purwoko, 2001). Untuk mencegah terjadinya kerusakan bahan makanan yang mengandung asam lemak tak-jenuh dan mengurangi risiko terkena penyakit akibat oksidasi tersebut dapat dilakukan dengan menggunakan antioksidan (Shahidi, 1997).

Antioksidan merupakan senyawa kimia yang dapat menunda, memperlambat dan mencegah proses oksidasi lemak (Kochhar dan Rossell, 1990). Salah satu tanaman yang mempunyai aktivitas antioksidan yaitu tanaman soyogik (Saurauia 
bracteosa DC). Kadji et al. (2013) telah melakukan penelitian mengenai aktivitas antioksidan dari ekstrak etanol daun soyogik yang diekstraksi dengan metode maserasi yang didapatkan hasil bahwa daun soyogik mengandung aktivitas antioksidan sangat kuat dengan nilai $\mathrm{IC}_{50}$ sebesar $38,01 \mathrm{ppm}$ dan pada pengujian fitokimia mengandung senyawa fenolik, flavonoid, steroid dan saponin. Penelitian selanjutnya dilakukan oleh Muaja et al. (2013) dan Maukar et al. (2013), menunjukkan bahwa ekstrak metanol dari daun soyogik mengandung senyawa fitokimia yaitu fenolik, flavonoid dan tanin, serta bersifat toksik. Senyawa fenolik yang terkandung dalam tanaman soyogik dapat berperan aktif sebagai antioksidan yang dapat menghambat dan menghentikan oksidasi lipid dengan cara mendonasikan atom hidrogen ke senyawa radikal membentuk intermediet radikal fenoksil (Nzaramba, 2008).

Berdasarkan penelitian-penelitian sebelumnya yang telah dilakukan, belum pernah dilakukan pengujian daun soyogik dalam menghambat terbentuknya oksidasi pada asam linoleat, oleh karena itu penulis tertarik meneliti lebih lanjut terhadap penghambatan oksidasi asam linoleat daun soyogik ini dalam menghambat oksidasi pada asam linoleat. Penelitian ini bertujuan untuk menganalisis kandungan total fenolik dan aktivitas antioksidan dari ekstrak metanol daun soyogik (Saurauia bracteosa DC) dalam menghambat oksidasi asam linoleat

\section{Material dan Metode}

Peralatan yang digunakan dalam penelitian ini adalah spektrofotometer UV-Vis (Shimadzu UV1800) dan bahan baku yang digunakan adalah daun soyogik (Saurauia bracteosa DC) yang diperoleh dari Desa Silian, Kecamatan Silian Raya, Kabupaten Minahasa Tenggara, provinsi Sulawesi Utara. Bahan kimia yang digunakan adalah pelarut organik metanol yang diredestilasi, reagen folin-ciocalteu $50 \%, \mathrm{Na}_{2} \mathrm{CO}_{3} 2 \%$, asam linoleat, etanol p.a, etanol $75 \%$, akuades, buffer fosfat $\mathrm{pH} 7$, amonium tiosianat $30 \%, \mathrm{FeCl}_{2}$ 0.02M, $\mathrm{HCl} 3.5 \%$, $\alpha$-tokoferol.

\section{Preparasi Sampe}

Sampel daun soyogik dibersihkan kemudian dikering-anginkan selama 1 minggu. Setelah kering sampel diblender hingga berbentuk serbuk lalu diayak dengan ayakan 65 mesh

Ekstraksi Metanol (Lisi, 2017)

Sebanyak $300 \mathrm{~g}$ serbuk daun soyogik diekstraksi dengan cara maserasi selama $3 \times 24$ jam menggunakan pelarut metanol sebanyak $4 \mathrm{~L}$. Selanjutnya disaring hingga diperoleh filtrat. Filtrat yang diperoleh kemudian dievaporasi menggunakan rotary evaporator. Kemudian dikeringkan dalam oven pada suhu $40^{\circ} \mathrm{C}$ hingga diperoleh ekstrak pekat.
Uji Kandungan Total Fenolik (Conde et al., 1997)

Kandungan total fenolik ditentukan dengan menggunakan metode Folin-Ciocalteu. Sebanyak $0,1 \mathrm{~mL}$ larutan ekstrak dan ditambahkan 0,1 $\mathrm{mL}$ reagen Folin-Ciocalteu 50\% lalu divortex kemudian ditambahkan $2 \mathrm{~mL} \mathrm{Na}_{2} \mathrm{CO}_{3} \quad 2 \%$ dan divortex. Selanjutnya campuran tersebut diinkubasi selama 30 menit. Absorbansi sampel dibaca pada panjang gelombang $750 \mathrm{~nm}$. Kandungan total fenolik dari ekstrak dihitung dengan menggunakan kurva standar asam galat.

Aktivitas Penghambatan Peroksida dengan Metode Ferric Thiocyanate (Chen et al., 1996)

Sebanyak $2 \mathrm{ml}$ buffer fosfat $\mathrm{pH} 7$, asam linoleat $50 \mathrm{mM}$ dalam etanol 99,8\% (2ml), dan $1 \mathrm{ml}$ aquades diletakkan pada vial gelap dengan tutup sekrup. Campuran tersebut diinkubasi pada suhu $37-40^{\circ} \mathrm{C}$. Analisis kadar peroksida dilakukan setiap 2 hari sebagai berikut. Kedalam $50 \mu \mathrm{l}$ sampel ditambahkan 2,35 $\mathrm{ml}$ etanol $75 \%$ dan $50 \mu \mathrm{l}$ amonium tiosianat $30 \%$, selanjutnya ditambahkan $50 \mu \mathrm{FeCl}_{2} 0,02 \mathrm{M}$ pada $3,5 \%$ larutan $\mathrm{HCl}$. Absorbansi diukur pada panjang gelombang $500 \mathrm{~nm}$. Berdasarkan pengukuran absorbansi peroksida blanko tersebut dapat ditentukan lama inkubasi untuk mencapai absorbansi maksimum (misalnya $\mathrm{x}$ hari). Prosedur yang sama seperti pada blanko, hanya aquades diganti dengan ekstrak sampel dan $\alpha$-tokoferol.

Persen penghambatan peroksida atau malonaldehida dihitung dengan rumus:

\section{Wpenghambatan $=100-\left(\frac{\text { absombansi sampel }}{\text { absombansiblanko }} \times 100 \%\right)$ \\ 3. Hasil dan Pembahasan \\ Ekstraksi \\ Penggunaan pelarut metanol pada proses} maserasi karena pelarut tersebut dapat melarutkan hampir semua senyawa metabolit sekunder. Hasil maserasi berupa cairan berwarna hijau tua. Maserat yang diperoleh dipekatkan hingga diperoleh ekstrak metanol berwarna hijau kehitaman sebesar 35,6 gram dengan rendemen 11,87\%. Tingginya rendemen ekstrak metanol disebabkan banyaknya jumlah seyawa polar yang terkandung dalam daun soyogik tersebut. Pada proses maserasi, sampel mengalami pemecahan dinding sel dan membran sel akibat perbedaan tekanan antara di dalam dan di luar sel sehingga metabolit sekunder yang ada dalam sitoplasma akan terlarut dalam pelarut.

\section{Kandungan Total Fenolik}

Uji kandungan total fenolik dengan metode Folin-Ciocalteu bertujuan untuk mengetahui jumlah fenol yang terkandung dalam ekstrak metanol daun soyogik. Metode ini didasarkan pada kemampuan ekstrak metanol untuk mereduksi reagen FolinCiocalteu yang mengandung senyawa fosfomolibdat dan asam fosfotungstat. Adapun kandungan total fenolik ekstrak metanol yaitu sebesar 99,67 mg/kg.

Kandungan total fenol yang tinggi pada ekstrak metanol menunjukkan bahwa senyawa fenol yang 
merupakan senyawa yang bersifat polar cenderung larut dalam pelarut polar (Harborne, 1987). Kandungan senyawa fenol pada ekstrak metanol berperan menentukan adanya kandungan antioksidan pada ekstrak metanol tersebut.

Penentuan Lama Inkubasi Sampel

Pengukuran aktivitas antioksidan ekstrak metanol daun soyogik dilakukan dengan menggunakan metode Ferric Thiocyanate (FTC).

Dalam penelitian ini digunakan sumber peroksida atau asam lemak yaitu asam linoleat. Sebelum dilakukan pengujian pada ekstrak metanol serta pembanding yaitu $\alpha$-tokoferol, dilakukan terlebih dahulu pengujian blanko seperti pada Gambar 1.

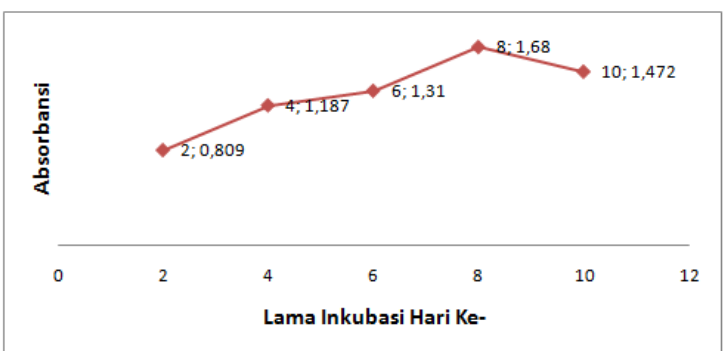

Gambar 1. Nilai absorbansi peroksida (blanko) dari asam linoleat selama inkubasi pada suhu $37-40^{\circ} \mathrm{C}$

Berdasarkan Gambar 1, pengujian blanko ini menggunakan akuades dengan prosedur inkubasi yang sama seperti sampel yang dibaca absorbansinya setiap 2 hari sekali dengan suhu inkubasi yaitu $37-40^{\circ} \mathrm{C}$. Pengujian blanko ini digunakan untuk menentukan lama inkubasi sampel sebelum dilakukan analisis peroksida pada sampel. Absorbansi mencapai maksimum pada hari ke-8 selama inkubasi 10 hari, yang menunjukkan pembentukan peroksida terus terjadi hingga hari ke8 akibat penurunan aktivitas antioksidan. Pada hari ke-10 terjadi dekomposisi peroksida.

\section{Aktivitas Penghambatan Peroksida dengan Metode Ferric Thiocyanate}

Pengujian pada sistem ini didasarkan pada kemampuan zat antioksidan ekstrak metanol daun soyogik untuk menghambat terbentuknya peroksida atau tahap awal terjadinya oksidasi lipid. Pada tahap awal oksidasi asam lemak tidak jenuh, terjadi autooksidasi membentuk radikal peroksida yang cukup banyak. Dengan adanya oksigen maka radikal bebas dari asam linoleat akan membentuk hidroperoksida $(\mathrm{ROOH})$ dalam suasana asam akan menghasilkan suatu oksigen tunggal yang kemudian akan mengoksidasi ion ferro $\left(\mathrm{Fe}^{2+}\right)$ menjadi ion ferri $\left(\mathrm{Fe}^{3+}\right)$ dan ion ferri yang terbentuk akan berikatan dengan ion tiosianat ( $\left.\mathrm{SCN}^{-}\right)$membentuk kompleks ferritiosianat $\left[\mathrm{Fe}(\mathrm{SCN})_{3}\right]$ yang berwarna merah. Merah pekat menunjukkan tingginya absorbansi dan rendahnya aktivitas antioksidan, sehingga efek penghambatan terbentuknya ion $\mathrm{Fe}^{3+}$ dievaluasi dengan melihat pembentukan kompleks ferritiosianat dengan menggunakan spektrofotometer pada panjang gelombang $500 \mathrm{~nm}$ (Natalia, 2016).
Persen penghambatan ekstrak metanol dalam menghambat oksidasi asam linoleat yaitu sebesar $49,464 \%$ dan $\alpha$-tokoferol sebesar 46, 964\%. Kemampuan ekstrak metanol dalam menghambat oksidasi primer memiliki hasil yang lebih tinggi dari $\alpha$-tokoferol sebagai pembanding. Hasil ini juga berhubungan dengan uji kandungan senyawa fenolik dimana ekstrak metanol memiliki kandungan fenolik yang tinggi. Nzaramba (2008) menyatakan bahwa komponen fenolik merupakan terminator dari radikal bebas dan sebagai pengkelat ion logam redoks aktif. Antioksidan fenolik ini menghalangi oksidasi lipid dan molekul lain dengan cara mendonasikan atom hidrogen ke senyawa radikal membentuk intermediet radikal fenoksil.

\section{Kesimpulan}

Kandungan total fenolik ekstrak metanol dari daun soyogik yaitu 99,67 mg/kg. Aktivitas penghambatan oksidasi asam linoleat ekstrak metanol dari daun soyogik dinyatakan dalam persen penghambatan dengan metode Ferric Thiocyanate sebesar 49,464\%. Ekstrak metanol memiliki kemampuan menghambat oksidasi asam linoleat lebih tinggi dibandingkan $\alpha$-Tokoferol sebagai pembanding.

\section{Daftar Pustaka}

Chen, H., Muramoto, K., Yamauchi, F., dan Nokihara, K. 1996. Antioxidant Activity of Designed Peptides Based on the Antioxidative Peptide Isolated from Digests of a Soybean Protein. Journal of Agricultural and Food Chemistry. 44: 2619-2623.

Conde, E.F., Cadahia, M.C., Garcia-Vallejo, B.F.D., Simon and Adrabos, J.R.G. 1997. Low Molecular Weight Polyphenol in Cork of Quercus Suber. J. Agric. Food. Chem. 45: 2695-2700.

Harborne, J. B. 1987. Uji Fitokimia. Bandung : Institut Teknologi Bandung.

Kadji, M. H., Runtuwene, M., dan Citraningtyas, G. 2013. Uji Fitokima dan Aktivitas Antioksidan dari Ekstrak Etanol Daun Soyogik (Saurauia bracteosa DC). Jurnal Pharmacon. $10: 5$.

Lisi, A., Runtuwene, M., dan Wewengkang, D. 2017. Uji Fitokimia dan Aktivitas Antioksidan dari Ekstrak Metanol Bunga Soyogik (Saurauia bracteosa DC). Jurnal Ilmiah - Farmasi. 1(6).

Maukar, M.A., Runtuwene, M.R.J dan Pontoh, J. 2013. Analisis Kandungan Fitokimia dari Uji Toksisitas Ekstrak Metanol Daun Soyogik (Saurauia bracteosa DC) dengan Menggunakan Metode Maserasi. Jurnal IImiah Sains .2(13): 98-101.

Muaja, D. A., Koleangan, S.J.H., dan Runtuwene, R.J.M. 2013. Uji Toksisitas dengan Metode BSLT dan Analisis Kandungan Fitokimia Ekstrak Daun Soyogik (Saurauia bracteosa DC) dengan Metode Soxhletasi. Jurnal MIPA Unsrat.2(2): 115-118. 
Natalia, A. H. S. 2016. Skrining Fitokimia dan Aktivitas Antioksidan Ekstrak Metanol Daun Rinu (Piper baccatum BI) [SKRIPSI]. Fakultas Farmasi Universitas Sanata Dharma, Yogyakarta.

Nzaramba, M.N. 2008. Relationships Among Antioxidants, Phenolics, and Specific Gravity in Potato Cultivars, and Evaluation of Wild Potato Species for Antioxidants, Glycoalkaloids, and Anti-Cancer Activity on Human Prostate and Colon Cancer Cells In Vitro. Disertasi. Texas A\&M University.

Purwoko, T. 2001. Aktivitas Antioksidan Isoflavon Aglikon dari Tempe terhadap Oksidasi Minyak Kedelai. BioSMART. 1(4).

Sartika, R. A. D. 2008. Pengaruh Asam Lemak Tak Jenuh Tidak Jenuh dan Asam Lemak Trans Terhadap Kesehatan. Jurnal Kesehatan Masyarakat Nasional. 2(4)

Tuminah, S. 2009. Efek Asam Lemak Jenuh dan Asam Lemak Tak Jenuh 'Trans' Terhadap Kesehatan. Media Penelit dan Pengembangan Kesehatan 